\title{
I was appointed governor
}

\author{
Barnabas Suebu
}

I was summoned to Jakarta and suddenly told to get ready to serve as governor. I was extremely surprised! I felt it was not time yet. I had only just turned 40. But because they were entrusting me, yes, I accepted and carried out the appointment.

Indeed, in the Indonesian political system at the time, ${ }^{1}$ the influence of the central government - or 'the centre' - was enormous. Even though elections involving several candidates, usually three to five people, were held through the Dewan Perwakilan Rakyat Daerah (DPRD, Regional Council of People's Representatives), the centre still had to be consulted on the decision. The centre had to first approve the election before it was held in the DPRD. And despite the election held by the DPRD, the final decision was still up to the centre. This was the situation (of politics in Indonesia) until Reformasi. The provincial DPRD might well elect A, but the centre could decide on B. So the election in the DPRD was just a formality. This really was undemocratic, since the centre was actually more determinant in the matter of appointing prospective governors. That was the mechanism in effect in those days.

And evidently the region did not reject me. The DPRD strongly supported my appointment because I was the chairman of the DPRD, so they knew me, and also, as it were, because due to my activities in the social sphere, I was widely known in the community, in youth and church circles. So maybe there was some competition between those who supported the A candidate or the B but at the time there was not much of a problem for me. What created problems was if the people favoured a candidate, but the centre rejected him. Yes, that constantly happened too. But in my case, the central government in Jakarta had no objections.

Barnabas Suebu first served as governor of Irian Jaya in 1988-1993. 
Yes, that was the way things were then. Today, perhaps, it would be a different story.

As for the course of my career up to the point when I became governor, it began first, perhaps, with social activities, and then the social activities became related to politics. When I first became active in Golongan Karya (Golkar, Party of the Functional Groups, the leading national political party) I did not became chairman right away, but after many years, starting from the bottom, from small things, then increasingly rising in position over time, eventually becoming chairman, which at that time was very hard. For in Golkar, only members of the Indonesian armed forces (ABRI) could become chairmen throughout Indonesia.

It was in 1981 that I became chairman of Golkar, both at the district and provincial levels. But it was a coincidence that I was entrusted for that. Moreover, I was a civilian, and also, a native of the region. Then, from there - since I was already a member of the DPRD due to my position as the chairman of Golkar - I was also entrusted as the chairman of the provincial DPRD. In this context there were political activities, but also government activities as well.

\section{DOUBLE POSTING}

I am a graduate of the Faculty of Law of Cendrawasih University (Uncen). I do not know how it got to the point that I could become governor. But my career only really departed from social activities. I liked being active in organizations, at first in youth organizations in the church, in the congregation, and then in the kecamatan (sub district), and after that, in a Christian student organization at school. In almost all of those organizations, they always selected me as chairman. At the village level as well as the sub-district level. And when I became a university student, I became the chairman of the Majelis Permusyawaratan Mahasiswa (MPM, Student Consultative Assembly), a student organization at Uncen.

Later on I served as the chairman of the Komite Nasional Pemuda Indonesia (KNPI, National Committee of Indonesian Youth) at the provincial level for a fairly long time, that is, eight years. And after that, I gradually became more and more active in politics, at the time in the Partai Kristen Indonesia (Parkindo, Indonesian Christian Party), which 
later on became the Partai Demokrasi Indonesia (PDI, Indonesian Democratic Party). Subsequently I moved to Golkar, which was the political party in power during the Soeharto government period, and I climbed up until I became the chairman of Golkar for the province of Irian Jaya.

Aside from that, I was also the chairman of the Kamar Dagang dan Industri (Kadin, Chamber of Commerce and Industry) of Irian Jaya province, an organization of entrepreneurs. Because I was not a civil servant, not part of the bureaucracy, it was alright for me to engage in business. So by the time I was 35 or 36 years old, I had already earned a bachelors' degree at Uncen, and was very active in a range of organizations. And at the same time, I was actively pursuing evening studies at Uncen to obtain a graduate degree.

At the time I was serving as the chairman of the Irian Jaya provincial DPRD, chairman of the Irian Jaya provincial branch of Kadin, chairman of the Irian Jaya provincial branch of Golkar, and also, still active as the chairman of the Irian Jaya provincial KNPI. I was extremely busy, but I was happy being involved in all those activities because it was a hobby, and not because I was a 'natural leader'. And at the same time I continued to be active in the church as the parish secretary of the Geraja Kristen Indonesia (GKI, Indonesian Christian Church) in Sentani. I was also active there as a church organizer, and so on.

\section{A NATIVE OF SENTANI}

I am originally from Sentani. I was raised in a village. My father was the first indigenous person in the history of evangelism in Sentani to work together with the missionaries who entered the area. So I used to accompany my father when he went into the villages with the missionaries. Back then there were no schools yet and people did not yet speak Malay, so my father helped the missionaries to translate their sermons and religious lessons for the people, especially in Central Sentani. So the missionaries travelled around the villages together with my father.

In Sentani I lived in the village of Ifale on Ayauw island. At the time Ifale was the gospel-spreading and school centre for Central Sentani. And it had also been the population distribution centre of the area since 
time immemorial, as there were not that many other villages in the vicinity. All the people originally resided on one island surrounded by a lake. They had probably settled there hundreds of years before; perhaps this needs to be researched. But based on the stories of the elders, all the inhabitants of the village spread themselves out and eventually formed the various villages found there today. Maybe long ago the population was not very big.

That was the story according to the phylogenetic history of the ondoafi besar (great adat chief) of the island. There was only one ondoafi besar for the island at first. Later, when the inhabitants spread out and formed villages, they had their own ondoafi as they do today. I was not a part of the family of the ondoafi besar. According to our family history, there was a relocation of people from kampung Tobati-Enggros, who came and joined the people of the lake I talked about before. Then it was from us that new villages were formed, whose number has now grown large. But everything was still centred on the island. The Suebu clan today provides the ondoafi in our village. Ondoafi Suebu comes from my family; he is not me but a member of my family.

\section{FOCUSING VILLAGE DEVELOPMENT}

After I was elected governor, my thinking was simple. I wanted to do something for the people in the villages. I have a vivid memory of my very first speech when I spoke about that. I said that I did not want to make grandiose promises, but I felt that the government, the state, the people and God had put their trust in me. Hopefully, with all the capabilities at my disposal, I could do something good for the people. But, I said, the people were in the villages. So I promised at the time that I would focus all of my policies on the villages. And I also remember well my last speech upon parting - also the last message I left to my replacement: pay attention the people in the villages!

Well, they were not just speeches! Every year I visited the villages for three or four months, non-stop. I never returned to the office. I slept in one village after another; I met with the people and all the village heads, all the village administrators and all the tribal chiefs. In the course of a single year, 12 months, I spent four months directly talking to the residents of the villages. And I brought along my whole staff, all the facili- 
ties, the whole budget, all of my knowledge. And at the time there were approximately 1,300 villages, in 135 kecamatan.

On my travels, I met directly with all the village heads and their wives and the administrators of all 1,300 villages. Yes, I met with them directly in a number of pre-determined places. Then I brought together the whole government apparatus - at the levels of the province and kabupaten, the government offices, the bupati, the camat, and we sat together and talked, and for two or three days we gave them training or instruction. If there were books on development packages from the past, we could look at how the former (Dutch) government implemented education, agriculture, health and governance in the villages.

In the villages we worked on improving people's knowledge. We called it the 'basic needs' project, focusing on things such as healthy housing, the continuous improvement of education, and good economics in the villages. We also taught them about good village governance and orderliness. We gave courses, then provided money and facilities, and I told them I would return the following year to check on their progress.

So we did not just speak high-flown words to the people in the villages. We were able to realistically achieve better standards of living from year to year. Using things that could be done by the villagers themselves, which at that time I called 'from them, by them and for them', with the resources available in the villages. We, the government, were there only to guide them, so they knew that these were their projects - for themselves and not for the government. And if they had no resources, we helped from the outside. Personally, I was happy with the programme, so each year I went around to the villages. Sometimes, when a minister summoned me to Jakarta, I sent my first deputy governor there, and told the minister that I was in the middle of going around to the villages, and the minister said: 'Okay, please just carry on!'

\section{SUPPORTED BY THE MINISTER OF HOME AFFAIRS}

Formerly, when Pak Rudini was the Minister of Home Affairs, he said: 'Oh, if that's the case I would like to come!' So there were times when he came to see our activities and joined in making speeches to the people in the villages, and he said, 'The programme is great! I must tell the other governors that they should all do this!' So that is my commitment to the 
villages. Why? Because I saw that the world of bureaucracy - I myself did not come from the bureaucracy - was too busy. Although they said that development was directed towards the people in the villages, development did not reach the villages properly. So when they (the government) were preoccupied with this project and that project, sometimes - no, not sometimes but almost always - it seemed the people were just watching the projects come in as if they were foreign affairs.

Outsiders came to work on things - that is, projects in the villages - then they went off, abandoning the projects, but taking the project money with them. This happened to the point that the villagers in one place in the interior got so angry they burned down a school building as well as a public health clinic. If I am not mistaken this happened in Enarotali.

It was because the entrepreneurs who came in from outside to build employed local villagers, but the villagers were cheated. They were not paid by the entrepreneurs who built those buildings. The people got angry, and burnt them down. Despite the fact that the buildings were in their own interests. That is why I protested to the government in Jakarta. Formerly, in the Dutch era, school buildings in the villages were built by the people themselves; the people did it on their own, without external help. So in the past, the Protestant and Catholic zendingen (missions) only sent teachers. But in the Indonesian era it was the reverse. Teachers were lacking, and government funds were used to build the buildings, but they were burned by the people!

Those in charge of construction were not local. Tenders came from outside the area and this brought financial losses. After we added everything up, the money spent was huge, involving billions and billions of rupiah! But several years after the buildings were constructed, they could not function any longer due to the lack of teachers. So then I asked why it was that such huge sums of money, billions and billions of rupiah, and by our calculations, as much as a trillion rupiah, could not be used to train teachers? The buildings could just be left to the people to construct, but the money would have helped us to maintain the participation of the people, or community self-help, in education, which had existed from time immemorial.

Teachers were a problem at that time. It was an example of how the central government policies were just based on the average, yes, made uniform. Schemes in Java were directly fabricated over here. I said: 'This 
can't be! Can't be! You are making policies uniform in the context of a nation that is not uniform. We are diverse.'

Well, sometimes they heard us, but the policies were already up and running, so they did not change. Yes, at the time all the policies were centrist, moreover, the projects were sectoral, coming from the top down, and here we served only as very rigid implementers, because we were afraid of Jakarta.

\section{CHANGING VILLAGE STRUCTURES}

During the time I served as governor the idea of changing the structure of the villages appeared. I immediately spoke with Pak Rudini, the Minister of Home Affairs, about the confusion this might create. And Pak Rudini said: 'Okay, I'll come!' When he came, I took him around to the villages. He observed village activities and we had opportunities to hold meetings, not only with me but also with village heads, community leaders and adat leaders. I said to the people, please talk to the minister so he knows that the standardized policies (from the centre) are incompatible with the socio-cultural conditions of people who live here.

One difference, for example, had to do with population size. Here, in one village there could sometimes be up to 200 household heads, sometimes only 50 in a village of perhaps only 100 residents, whereas the population of a single village in Java could be thousands of people. So in Java, the population of a very small area could be 100 times greater. Here the territory was vast, but its population was small. Take, for example, Mamberamo-Hulu, where the distance between one settlement and another took a week to cross on foot. But Mamberamo-Hulu was one village.

Another issue was, who should serve as village head? Yes, a village head had to live in the village he governed. If he did not live in the village, he would be culturally disassociated from the residents of the village, and they would reject him. That too was very different from the situation in Java. So the minister of home affairs tried to understand, and then made some new adjustments, basically to restore the old village patterns. Let us accept village communities as they are, not see them in terms of their population sizes. The population of one village in Pakistan is not the same as the population of a village here. The population of the 
island of Java is 100 million, but here it is one million, only one percent! Thus, coming back to the village, it need not depend on population size! Villages had adat lands with boundaries that people from other villages or cultures could not enter. That was the state of the villages at the time.

Finally, the centre did make adjustments, so that the number of villages here multiplied. Before, for example, two or three villages had been merged into one village, or four villages into one village, so the number of villages grew when the adjustments were made. Indeed, the decision came from Jakarta, from the minister of home affairs, but it was we who delivered the proposal to Jakarta.

\section{THREE PILLARS}

At that time we not only rearranged the villages, but also developed the villages. Village development was based on the philosophy I applied at the time, namely: from the village, by the village, and for the village. Developing by using what was available in the village, working with the available resources of the village - that was the primary principle. In that spirit we developed, with the help of the government and non-government or community organizations or the church, or what we called the 'three pillars' at the time. The three pillars were: first, adat; second, the church or community or non-government organizations; and third, the government. All of them came to help, guide, direct and educate villagers to develop. It was not we who developed them, but they who had to develop. At the time I used a bicycle as an example: it is not we, but they who must ride the bicycle. We only helped train people so they could ride the bicycle. Because at the time, the line of thinking was, do not give them the 'bicycle' because they do not know how to ride it. They could, however, be trained in riding the bicycle even though they might not know how to do so at first. Like a child who is learning to ride a bicycle: he often falls down, but eventually he can do it. In short, it was something like that.

Indeed, the existence of structural changes also had an effect on community or adat leaders. There were government regulations, for example, that called for a village head to fulfill a number of requirements. But I said that these rules could only be enforced in the cities, but the farther into the interior you went, the less the rules could be applied, for example, the educational requirements. 
Yes, because over there, the adat leaders could well serve as village heads even if they did not meet the government (regulation) requirements. So, at the time we advised Jakarta to change that regulation. Then, for example, in cases where the adat leader was not the village head, he should be given a place of honour in the village government structure, and take part in making decisions in village government.

And that is the reason why the Lembaga Musyawarah Desa (LMD, Village Consultative Assembly, an assembly of appointed village people) and Lembaga Ketahanan Masyarakat Desa (LKMD, Village Community Resilience Council) were established. Adat leaders also sat on these councils. At the time there was a rule that the village head also doubled as the chairman of the LMD. We filed an objection to Jakarta that older people could serve as the chairmen of that institution. So, it did not have to be the village head who was the chairman. Those were the sorts of things we tried to improve upon at that time.

Regarding the Badan Perwakilan Desa (BPD, Village Representative Board), it was only the term that changed. It was formerly called the Lembaga Musyawarah Desa, but is now called the Badan Perwakilan Masyarakat (BPM, Community Representative Board) or the BPD. Its function is almost the same, and there is also the LKMD. What the names of these institutions are in the new laws I do not know, as I have been working abroad. ${ }^{2}$ But the essential point is that adat leaders can no longer be as they were in the past, when they were left outside of the structure and their positions were not accommodated. Despite the fact that all the people of the villages in the interior must obey their adat leaders. So there might well be two leaders in a single village. Well this was ineffective. This is why it was decided to unite the two into one structure. That way, there would no longer be two leaders in one village.

\section{ABOUT PAPUAN PARTIES}

About the recent desire to reshape the Partai Nasional (Parna, National Party) advanced by Herman Wayoi: Yes indeed, the frame of the Republic of Indonesia came first, but frankly, there was also a new school of thought about getting outside the frame of the Republic of

\footnotetext{
2 At the time of the interview, in July 2000 in Jayapura, Barnabas Suebu was Ambassador of the Indonesian Republic for Mexico, Honduras, and Panama (1999-2002).
} 
Indonesia. It was an aspiration for independence. And conditions were conducive to a kind of transition. So perhaps the way of thinking of Pak Wayoi, for example - as I have recently heard - his frame of thought may be broader, it may apply both outside and inside the frame of the State of the Republic of Indonesia. However, if we just limit ourselves to what has happened inside the frame of the Republic of Indonesia, enormous changes have occurred as a result of Reformasi. Golkar, the former ruling party, is no longer in power, and there is the Partai Demokrasi Indonesia Perjuangan (PDI-P, Indonesian Democratic Party of Struggle). Formerly, there were only three political parties; now there are already 40 ! And some of those parties are also found in this province.

Well, as for the extremists who want independence, they have thought about their political parties after independence, but this is totally separate from the system of political parties in Indonesia. Yet there are also, for example, those who want to fight for Papua, who think: why not form a Papuan political party that will fight within the Indonesian political arena? Yes, this could be because people form political parties according to the laws of Indonesia and must, of course, meet a number of specific requirements in accordance with the law. So, if it is within this framework that Pak Wayoi, for example, wants to form the National Party, I think there is no problem, even though it has often been expressed that political parties should not be too tribal. If people in Jakarta say that parties should be more national, yes, of course, it would not be tribal.

Regarding the new political parties, I think that they need to be socialized to the public. Meaning that the people must become familiar with these parties; who their leaders are, what their goals are, and what benefits they would bring the community. Only if a new political party succeeds in becoming widely known can it gain the sympathies of the people, and perhaps also, their support. So people will look at their systems as well as who their leaders are. For the people in Papua, leaders are important and must be figures who people trust, and this takes time. And it depends on the party itself. In the past (the New Order) there were only three political parties - Golkar, PDI, and PPP - which had been known for years, especially Golkar, whose foothold reached as far as the villages.

Thus, during the last election, the ones the people had known for years were these three political parties: Golkar, PDI, and PPP. But as the general election came closer - because of Reformasi - the three parties 
expanded to become 40 or more. The people had not yet had a chance, not yet had enough time to get to know the parties well, and went directly into a general election. That is why some of the people were confused, because some of them, for example, still knew Golkar, and perhaps in the past they had voted for either Golkar or PDI, but because they were disappointed with Golkar, they had swung their votes to PDI-P. This was the national picture, outside of Papua. That is why PDI-P, which used to be small, rose to become such a large party. Golkar had always gained a majority of the votes in the general elections during the New Order period. But as a result of Reformasi, many votes ran to the PDI-P. This also happened in Papua, although here Golkar remained on top, and the PDI-P came in second. But outside of Papua, nationally speaking, on the average PDI-P was ahead of Golkar.

\section{RECOGNIZE THE VILLAGES}

I am really not a professional civil servant, in the sense of being educated and trained in the bureaucracy, but because of my experiences at that time (in organizing and engaging in politics) I was entrusted to be the governor here. I think that the most important message I would like to send, and at the same time leave people with is: Recognize the people in the villages properly! Know their circumstances, their strengths, their weaknesses, and the resources that they have, so these can be exploited as potentials for their development. That is the essence of the message I want to send!

Development or governance begins from human beings and ends with human beings, and human beings live in groups, and the smallest of the groups they form are the villages. So, we just provide them with something that further improves their lives, raises their standards of living to to make them prosper. Do it simply: there is no need for highsounding promises of development because they do not think in lofty terms, their hopes are not that high. Yes, they want a good education and certain kinds of useful the knowledge, as well as good health, better and healthier houses, a healthy environment, and a peaceful and orderly environment. I think those are the life values they need in the villages. There is no need to proceed as if one were developing a metropolitan city. What if they felt pleased and content in their own environments, yes, 
and what is more, in pursuing what they wanted in life, once their hearts were happy? This is what the focus of government work should be.

Thus, government would blossom, grow, and flourish from below, starting from the villages. Only further up, at the kecamatan level, would 'middle management' be set up as the spearhead to direct things upwards to the kabupaten, then the province. So let us not, as civil servants preoccupied every day at the office, in front of our desks, in a world of bureaucracy, act as if we are taking care of the people, but only take care of them on paper! Whereas the people themselves receive nothing! Sometimes the people serve only as spectators, without having rights or feeling any sense of ownership, and so on and so forth. So, yes, that is my message! 